\title{
Variation in Indonesian cocoa farm productivity in relation to management, environmental and edaphic factors
}

Article

Accepted Version

Daymond, A. J., Prawoto, A., Abdoellah, S., Soetanto, A., Susilo, A. W., Cryer, N. C., Lahive, F. and Hadley, P. (2020) Variation in Indonesian cocoa farm productivity in relation to management, environmental and edaphic factors.

Experimental Agriculture, 56 (5). pp. 738-751. ISSN 00144797 doi: https://doi.org/10.1017/S0014479720000289 Available at https://centaur.reading.ac.uk/93223/

It is advisable to refer to the publisher's version if you intend to cite from the work. See Guidance on citing.

To link to this article DOI: http://dx.doi.org/10.1017/S0014479720000289

Publisher: Cambridge University Press

All outputs in CentAUR are protected by Intellectual Property Rights law, including copyright law. Copyright and IPR is retained by the creators or other copyright holders. Terms and conditions for use of this material are defined in the End User Agreement. 


\section{CentAUR}

Central Archive at the University of Reading

Reading's research outputs online 
2

3 Variation in Indonesian cocoa farm productivity in relation to 4 management, environmental and edaphic factors 5

6 A.J. Daymond ${ }^{1 *}$, A. Prawoto ${ }^{2}$, S. Abdoellah², A.W. Susilo ${ }^{2}$, N.C. Cryer ${ }^{3}$, F. Lahive ${ }^{1}$, P. Hadley ${ }^{1}$

8

${ }^{1}$ School of Agriculture, Policy and Development, The University of Reading, Whiteknights, Reading, RG6 6AR, UK Indonesia 
A survey was conducted of Indonesian cocoa farms to assess the extent of yield variation and factors associated with this variation. The survey of 120 farms during the course of three years encompassed four provinces in Sulawesi (South, South-East, West and Central), Western Sumatra, Lampung, East Java and West Papua. A high degree of yield variation was observed between farms, the average over three years ranged from 39 to $3586 \mathrm{~kg} \mathrm{ha}^{-1}$. Overall, yields were greater on farms that were classified as "highly managed", compared to "moderately" and "less managed". Seasonal variability in yields was generally greater in districts with a more pronounced dry season such as South Sulawesi and Lampung.

Multiple regression analyses revealed particular husbandry practices that were linked with higher cocoa yields. Specifically, the use of inorganic fertilisers, application of fungicides against blackpod and weeding were all practices that were associated with higher yields. A positive association between rainfall and yield was observed for the years 2014/15 and 2015/16 but not 2016/17, which was a La Niña year (when rainfall totals were higher). Some of the farms surveyed were planted with cocoa at very low densities implying an opportunity for yield improvement through gap filling or replanting at higher densities (although it was noted that some farmers maintained lower planting densities due to the cultivation of companion crops).

Given the smallholder status of most cocoa farms in Indonesia (mean area in this study was 0.71 ha) it is important that farmers are able to maximise returns from their land in order to maintain a livelihood. This study illustrated the potential for yield improvement on Indonesian cocoa farms through adoption of best agronomic practice.

\section{Introduction}

Indonesia is currently the fifth largest cocoa producer globally and by far the largest producer within south-east Asia (ICCO, 2019), the sector having undergone a period of rapid expansion during the 1980s and 1990s (Juhrbandt et al., 2010). The bulk of cocoa is produced by an estimated one million small-holder farmers (Sefriadi et al., 2013), typically on plots of land that are less than 2 ha. Farmers will often intercrop the cocoa with other tree species such as coconut, which provide an additional source of income.

Compared with other cocoa-growing countries, the geographical distribution of cocoa cultivation is very widespread, ranging from Sumatra in the west to West Papua in the east; over $60 \%$ of Indonesia's cocoa production is on the island of Sulawesi (McMahon et al., 2015). Differences in climatic conditions occur across these growing regions, for example, most of Sulawesi has a distinct but short dry season, East Java has a longer dry season whereas Western Sumatra and West Papua tend to experience relatively constant rainfall all year round. Furthermore, there are contrasting husbandry practices in different provinces. For example, the use of side-grafting to rehabilitate old cocoa trees is most widely observed in Sulawesi, whereas in West Papua farmers apply a minimal amount of crop husbandry in terms of, for example, fertiliser addition and pest control. A mixture of hybrid and clonal material is cultivated in Indonesia, with clonal cultivation having expanded in Sulawesi (Dinarti et al. 2015), although clonal cultivation is less prevalent in Sumatra and Java.

In recent years there has been a national decline in total cocoa production in Indonesia (ICCO, 2019). This may be due, in part, to farmers switching to less labour-intensive crops, such as oil palm (Mulia et al., 2019). Furthermore, factors such as pests and diseases and soil fertility decline can put 
downward pressure on yields (Ruf and Yoddang, 2001), the key pests and diseases being blackpod (causal agent: Phytophthora palmivora), vascular streak dieback (causal agent: Ceratobasidium theobromae), cocoa pod borer (Conopomorpha cramerella) and mosquito bug (Helopeltis theobromae). If cocoa farming is to remain attractive to Indonesian smallholders then it is important that farmers are able to achieve an economically viable yield through optimal and sustainable management practices on their farms. Maintaining and improving on-farm cocoa yields will also reduce pressure on remaining forest lands.

This study set out to ascertain the extent of farm-to-farm variation in yields in Indonesia across the main growing regions and to explore the hypothesis that a significant proportion of this variation can be attributed to specific farm husbandry practices, climatic and edaphic factors. To achieve this, farms were regularly monitored over a three-year period to assess their yields and farming practices were determined by means of farmer interviews.

\section{Materials and Methods}

\section{Farm Selection}

Farms were selected for investigation in March-April 2014. Eight provinces were chosen to reflect both current important areas of production and anticipated future key areas of production. The provinces chosen were: Western Sumatra, Lampung, West Sulawesi, Central Sulawesi, South-East Sulawesi, South Sulawesi, East Java and West Papua. Within each province, fifteen farms were selected from three districts, except for West Papua where two districts were chosen. The criterion for farm selection was that there should be five farms in each province for which the management was considered "highly managed" (farmers routinely fertilise, prune and apply pesticide; cocoa farming was the farmer's main source of income), five for which the management was considered "moderately managed" (farmers sometimes fertilise, prune and apply pesticide) and five for which the management was classified as "little managed" (famers rarely fertilise, prune and apply pesticide; cocoa farming was not the farmer's main source of income). Where possible, a mixture of farms with seed-grown and with grafted (clonal) cocoa were selected in each province.

\section{Farm Characteristics}

The size of each farm was measured using a GPS device (Garmin, GPSmap 76CSX) and the number of cocoa trees were counted in order to calculate tree density. The shade trees present on each farm were also recorded. Radiation interception by the cocoa trees was measured in 2014. For this, a vertical photograph was taken below the cocoa canopy using an SLR camera fitted with a fish-eye lens (Nikon, D5100). Four images were taken per farm and these were then analysed using Hemiview Software (Delta-T Devices, Cambridge, UK) to obtain a mean light transmission value (T). Percentage light interception was calculated as $(1-\mathrm{T}) * 100$.

Soil samples were obtained by soil auger at a depth of $20-30 \mathrm{~cm}$ and combined from 4 cores on each farm. A sample of approximately $0.5 \mathrm{~kg}$ was collected. $\mathrm{N}$ analysis was conducted using the micro Kjieldahl method, $\mathrm{P}$ by Bray 1 or Olsen (depending on the $\mathrm{pH}$ ), potassium by means of ammonium acetate extraction with the filtrate read by atomic absorption spectrometry (Perkin Elmer Lamda 25) and carbon using the Walkey and Black method (Walkey and Black, 1934). 
Farmers were interviewed between April and May 2014 and subsequently at the same time of the year in 2015 and 2016. The farmers were asked about their farming practices that included whether or not they applied fertilizer (organic and inorganic) and control of pests and diseases, specifically blackpod disease (Phytophthora palmivora), vascular-streak dieback (Ceratobasidium theobromae) and cocoa pod borer (Conopomorpha cramerella). They were also asked about benefits and problems associated with companion shade trees and factors that limited their ability to use fertiliser.

\section{Meteorological Data}

Small dataloggers (Tinytag, Gemini Dataloggers Ltd, Chichester, UK) were placed in a shaded area on 23 of the farms (one in each district) and set to record temperature and relative humidity at half hour intervals. Monthly rainfall data was provided by the Indonesian Meteorological, Climatological, and Geophysical Agency. These data are summarised in Table 1.

\section{Yield Variation}

At the beginning of the data collection period, 16 trees were marked randomly on each farm for subsequent observations. Assessments of on-farm productivity were made from April 2014 at sixweekly intervals and the number of fruits (commonly termed and subsequently referred to as "pods") on each labelled tree were counted in different size classes ("Tiny" $=<2.5 \mathrm{~cm}$ in length, "Small"= 2.5-7.5 cm; "Medium"= 7.5 to $15 \mathrm{~cm}$; "Large" $=>15 \mathrm{~cm}$, "Ripe" = pods showing distinct colour changes). To assess the number of pods harvested between two treks, $t_{1}$ and $t_{2}$, the following formula was used:-

Number of pods harvested at $t_{2}=$

$\Sigma$ (number of large and ripe pods at $t_{1}$ ) - number of pods that have progressed from large to ripe

An assumption was made that, between two time points, all ripe pods would have been harvested, whereas a large pod may either progress to the ripe category or else may go all the way to harvest. The number of pods per hectare was then calculated by multiplying the number of pods per tree by the planting density (trees per hectare). Yields in terms of dry bean per hectare were then calculated by dividing by the pod index (the number of pods required to produce one $\mathrm{kg}$ of dry beans) estimated for each farm. Pod indices were determined from a minimum of 20 pods per farm during 2014. For the year 2014/15, estimated yields were compared with the farmer's yield records; where there was a large discrepancy, farms were excluded from the analyses.

At each farm visit, the number of pods infected with blackpod (Phytophthora palmivora) was also recorded in the "medium", "large" and "ripe categories". When calculating percentage losses due to blackpod, two assumptions were made: any infected pods that were recorded at a period of data collection would have been removed by the farmer by the time of the subsequent data collection (six weeks later); any pods infected at the "tiny" or "small" stage would have made little difference to the overall yield since a proportion of juvenile pods are naturally aborted through "cherelle wilt" (a pod-thinning process in cocoa, Nichols, 1964) and therefore were not counted. Note data from 
2015 for W Papua are not included in the analyses due to logistical issues in collecting data for a part of this period.

On each farm visit a visual assessment was made of the proportion of weed cover (\%) and also the quality of pruning that had taken place. The latter was classified into the following categories: "Little" (visual evidence of a small amount of pruning, if at all), "Moderate" (visual evidence of a moderate amount of pruning but the canopies not sufficiently opened up), "Optimum" (pruning to a level that allows light penetration through the canopy), "Excessive" (more pruning than is necessary, meaning that the tree takes some time to recover from the pruning event).

\section{Data analysis}

Differences in yields between farm categories were analysed by means of analysis of variance (ANOVA) as were differences between provinces for a range of farm and soil parameters.

Factors underlying farm-to-farm yield variation were analysed on a per tree basis, firstly as pods per tree and then dry beans per tree. Conducting the analysis on a per tree basis enabled the impact of tree density to be examined as an independent variable to the response variable. The analysis used the backward stepwise variable selection method of Draper and Smith (1998). The factors initially included in the model are summarised in Table 2. In the case of temperature data, data were used from the nearest farm that had a datalogger on it. First order interactions between planting material and the other listed factors were also included. The interaction between rainfall and spraying against blackpod was also included, since greater rainfall may have been associated with higher disease pressure. Data were log-transformed when they deviated from a normal distribution.

For each year the model was repeated using three measures of rainfall:-

1. Total rainfall for the period of six months prior to the start of the trek year up until three months prior to the end of the trek year (the period that rainfall can potentially influence the crop in terms of flowering, pod setting and "cherelle wilt", the latter being wilting of developing pods due to insufficient assimilate availability. The period from flowering to pod maturity is six months and cherelle wilt occurs up to approximately six months before harvest; Nicols, 1964).

2. The number of consecutive dry months for the aforementioned period.

3. The total number of dry months for the aforementioned period.

The relationship between seasonal variation in yield within each district and rainfall was examined by means of regression analysis. These were conducted iteratively using different periods of rainfall (Six months prior to cropping corresponding to the time of flowering; five months prior to cropping corresponding to the time of pod setting and initial pod growth; four months prior to cropping; five to six months before cropping; four to six months before cropping).

The relationship between farmer socio-economic factors (gender, farmer age and level of education) with yield was examined by means of chi-square. 
Results

Yield

The distribution of yields (dry beans per hectare) between farms within and between management categories ("Highly managed", "Moderately managed" and "Little managed") over the three-year period is summarised in Figure 1. Overall, large differences in yields (expressed as dry beans ha ${ }^{-1}$ ) were recorded. Annual yields averaged over the three years ranged from ( 39 to $3586 \mathrm{~kg} \mathrm{ha}^{-1}$ ). On average, yields were higher in those farms classified as "Highly managed" (mean = $1343 \mathrm{~kg} \mathrm{ha}^{-1}$; median $\left.=1126 \mathrm{~kg} \mathrm{ha}^{-1}\right)$, compared to "Moderately managed" (mean $=879 \mathrm{~kg} \mathrm{ha}^{-1}$; median $=770 \mathrm{~kg}$ $\mathrm{ha}^{-1}$ ) and "Little managed" ( mean $=908 \mathrm{~kg} \mathrm{ha}^{-1}$; median $\left.=594 \mathrm{~kg} \mathrm{ha}^{-1}\right)(\mathrm{P}<0.001)$.

Cropping patterns over three years are displayed in Figure 2 for all eight provinces studied. Within Sulawesi, the most pronounced cropping peaks were observed within West and South-East Sulawesi in May and July, respectively. Within the island of Sumatra, much more pronounced cropping peaks were observed in Lampung (in June/July) compared with Western Sumatra. The cropping pattern was relatively flat in East Java and in West Papua, the latter of which experienced heavy rainfall all year round.

Overall estimated losses to blackpod measured over the three seasons was $17 \%$. Losses were considerably higher in W Papua (46\%), Western Sumatra (28\%) and Central Sulawesi (27\%).

\section{Farmer profiles}

The largest proportion of farmers (32\%) was in the $41-50$ age group; approximately $15 \%$ of farmers were over 60 . Most famers had at least some level of school education, whilst $8.6 \%$ of farmers were university-educated. Less than $2 \%$ of farmers had no education at all. The vast majority of the farmers $(96 \%)$ owned their own farms.

\section{Physical characteristics of cocoa farms}

The mean size of the farms was 0.71 hectares, although the distribution of farm size was skewed such that a larger proportion fell below the mean; the median farm size was 0.63 ha. The overall range of farm sizes was 0.11 to 3.2 hectares (Figure $3 \mathrm{~A}$ ). The largest farms were in West Papua and the smallest in West Sulawesi, although overall there were no significant differences in farm size between provinces. Cocoa trees were planted at regular spacings on most of the farms.

Cocoa tree density varied greatly between farms; the average was 888 trees per hectare. The distribution was skewed such that a small number of farms were planted at high densities (median = 775 trees per hectare). The range of cocoa tree densities was 272 to 2598 trees per hectare. Significant differences were apparent between provinces ( $P<0.05$, ANOVA test; Figure 3B). The highest planting densities were observed in the four provinces within Sulawesi, whilst the lowest was in East Java. The average proportion of radiation intercepted by the cocoa canopy was $67 \%$.

The shade tree species present on the farms are summarised in Table 3. Only 5\% of farmers grew cocoa without shade. The most widely utilised shade tree species was coconut, observed on $42.5 \%$ of farms, followed by Glyricidia sepium ( $33.4 \%$ of farms). The main benefits cited by cocoa farmers for the use of shade were additional income $(46.6 \%$ of respondents) and reduction in thermal and water deficit stress $(40.7 \%$ of respondents). Most farmers $(77.1 \%)$ did not cite a specific problem 
associated with overhead shade. Of those that did, competition with cocoa was cited by $14.4 \%$ of respondents.

The mean age of the farms was 15 years, ranging from 2 to 34 years (Figure 3C). Overall, farms were younger in Western Sumatra compared with the other provinces $(P<0.05)$, reflecting the more recent spread of cultivation of cocoa into this province.

In terms of soil characteristics, significant differences were observed between provinces in soil pH $(P<0.001)$, the most acid soils were in Western Sumatra, West Sulawesi and South-East Sulawesi. Significant differences were also found between provinces in soil carbon and soil nitrogen $(P<0.001$ in both cases), such that the highest levels of these two nutrients were observed in Western Sumatra and West Papua (Table 4).

In the case of available phosphorus differences between provinces were on the borderline of significance $(P=0.058)$. Here, there was a considerable amount of variation between farms within provinces. Overall, the lowest levels of available phosphorus were observed in W Papua. Potassium concentration varied significantly between provinces $(P<0.001)$, the lowest levels being seen in South-East Sulawesi. In the case of magnesium, higher soil concentrations were in West and South Sulawesi compared with other provinces $(P<0.001)$.

\section{Farming practices}

A large proportion of farmers applied inorganic fertilisers (81\% in 2014, falling to $78.4 \%$ in 2016). Use of fertiliser was less prevalent in West Papua. Farmers were asked in 2015 and 2016 about factors that limited their ability to apply fertilisers. In $2015,40 \%$ of farmers said that they did not face any limitations and this fell slightly to $34 \%$ in 2016 . The most commonly cited limiting factor was insufficient funds (43 and 35\% in 2015 and 2016, respectively).

Overall, approximately one third of farmers sprayed fungicides against blackpod, although the proportion varied slightly between years (28.8\% in 2015, 35.8\% in 2014 and $39.7 \%$ in 2016). Regarding insect control, a large proportion of farmers sprayed insecticides against cocoa pod borer (72.5\% in 2014, 73.7\% in 2015 and $69.8 \%$ in 2016). The proportion of farmers that sprayed pesticides against Helopeltis was slightly lower (60.8\% in 2014 but falling to $46.6 \%$ in 2016).

\section{Factors Underlying Farm-to-Farm Yield Variation}

Fitted multiple regression models of factors relating to yield variability are presented in Table 5 . The best fitted models were achieved when pods per tree was used as the response variable. For the years $2014 / 15$ and $2015 / 16$ the model accounted for $51.3 \%$ and $46.6 \%$ of the variability, respectively. The model for $2016 / 17$ accounted for less of the variability (33.5\%). There were a number of common factors in the models for 2014/15 and 2015/16, specifically a positive association with rainfall and with spraying fungicides against blackpod. For the 2014/15 model there was a negative association with the number of consecutive dry months and yield, whereas for 2015/16 the best fit was obtained for total rainfall (for which there was a positive association with yield). In 2015/16, a positive association between farm age and yield was observed, whilst there was a negative association with amount of weed cover and yield. In terms of soil characteristics, a positive association was seen between available phosphorus and yield in 2015/16 and 2016/17, whilst a negative association was observed between soil potassium and yield in all three years. 
No associations were observed between farmer socio-economic characteristics (gender, farmer age or level of education) and farm-to-farm yield variation.

\section{Factors Underlying Seasonal Yield Variation}

Significant positive relationships were noted in several districts between rainfall and seasonal yield variation as summarised in Table 6.

\section{Discussion}

A high degree of variation in yields was observed between small holder cocoa farms in Indonesia. Crop husbandry accounted for at least a part of this variation; overall farms that were classified as "highly managed" had higher yields and multiple regressions analysis revealed positive associations between management practices including fertiliser input and blackpod control with yield. The fact that there was less variation amongst the "Highly managed" farms might indicate that these farms are closer to their maximum production potential. Average farm yields observed in the current survey are higher than those that have been quoted by others, for example, Witjaksono and Asmin (2016) quote annual yields of 500-700 kg ha-1. However, this is probably a reflection of the fact that in our survey two-thirds of the farms were deliberately sampled within the well and moderately managed categories, which is likely to be a higher proportion of farms that fall within these categories nationally. Furthermore, the estimated yields presented are potential yields in the absence of cocoa pod borer infestation, which was observed to be high on some farms (data not shown). Five farms had three-year estimated average dry bean yield above three tonnes $\mathrm{ha}^{-1}$, although longer records would be needed to establish whether such high yields could be maintained over time.

Seasonal yield variation was greatest in parts of Sulawesi and in Lampung. It would appear that at least part of the observed seasonal variability in yields could be related to rainfall patterns. Generally, where a more pronounced dry season was observed, this was associated with greater yield variation. The fact that stronger correlations were detected between rainfall and yield in some districts compared with others may be in part a reflection of differences in soil moisture retention properties. Previous research in Indonesia has demonstrated that withholding rainfall using rain shelters had the effect of reducing subsequent yields (Moser et al., 2010).

A high degree of heterogeneity was also observed in the physical characteristics of farms. The average farm size observed in our survey (mean $=0.71$ ha) was similar to a study of cocoa farms in Central Sulawesi where an average farm size of 0.63 hectares was reported, ranging from 0.4 to 3.3 hectares (Juhrbandt et al., 2010). Furthermore, Panlibuton and Meyer (2004) indicated that the majority of cocoa in Sulawesi was produced on farms ranging in area from 0.5 and 1.5 hectares. Syamsinar et al. (2014) reported larger cocoa farms in South Sulawesi ranging from 0.3 to 8.75 hectares. However, just over half the farms in their survey were greater than 1 hectare. In order to maintain a livelihood from such small plots of land maximisation of yield per hectare is clearly important.

One way of achieving higher land returns can be through optimisation of planting density. According to Ruf et al. (1995), cocoa planting densities on smallholdings in Indonesia usually range from about 1000 to 1300 trees per hectare. Here, over half of the farms within our survey were outside of this range (both lower and higher). Some of the farms surveyed were planted at very low densities and 
so there is the opportunity for yield improvement on such farms through gap filling or incremental replanting at higher densities. The observation of planting in rows on most farms is in contrast to a more variable planting arrangement commonly observed in West Africa. Uniform spatial arrangement has the advantage that it reduces competition between trees (in terms of light, water and nutrition) and also makes management of the crop easier (e.g. when it comes to spraying).

Cocoa farmers may deliberately leave larger gaps between some rows in order to accommodate companion overhead shade species, which may result in the overall cocoa density on the farm being lower than recommendations. The use of companion overhead shade trees was common amongst the farms surveyed and was cited as an additional source of income by almost half of the farmers. A number of shade tree species recorded here were also observed on cocoa farms in Central Sulawesi by Clough et al. (2009) including G. sepium, Rambutan, Avocado, Lansium tree, Dadap and Durian. The same authors also noted the presence of Aleurites moluccana (candlenut), sugar palm, sago palm, Ficus species, Pterospermum celebicum and Bischofia javanica (Bishop wood). According to Belsky and Siebert (2003) full sun cocoa is becoming increasingly common in Central Sulawesi. However, in our survey, shade trees were present on 14 out of the 15 farms in this province. Whilst no differences in yields were observed between shaded and non-shaded farms it is still plausible that different shade intensities may have contributed towards yield variation.

The proportion of farmers applying inorganic fertiliser in our survey may be higher than that in the country as a whole, for example Sefriadi et al. (2013) in a sample of 100 cocoa farmers in Western Sumatra, found that $69 \%$ of farmers applied some sort of fertiliser. A positive impact of inorganic fertiliser addition on yield was apparent in 2014/15 and the same, although non-significant trends were also observed for 2015/16 and 2016/17, implying a benefit of fertiliser addition. Nevertheless, the impact of fertilisers will be greater and more cost-effective if the quantity and type is matched to local soil conditions. Where soils are depleted, inorganic fertiliser applied alone may have little or no impact (as demonstrated by Mulia et al., 2019 on marginal acidic soils in North Luwu, South Sulawesi). Optimisation of the use of inorganic fertiliser is particularly important given the cost restraints cited by 43 and 35\% of farmers in 2015 and 2016, respectively. A positive association was observed between available soil phosphorus and yield for 2015/16 and 2016/2017 suggesting that this may be a limiting factor for yields. The negative association between soil potassium concentration and yields observed in the models might seem counterintuitive. No farms were below the minimal threshold for potassium $\left(0.2 \mathrm{cmol}_{\mathrm{c} \mathrm{kg}}{ }^{-1}\right)$ proposed by Snoeck et al. (2016). However, compared with other provinces, lower soil concentrations of potassium were observed in South-East Sulawesi, where conditions and practices were otherwise favourable towards higher yields. Therefore, the negative association between soil potassium and yield may have been an artefact of lower (but not limiting) soil concentrations in South-East Sulawesi.

A positive impact on yield of spraying against blackpod (Phytophthora palmivora) was also observed. Blackpod is a major disease of cocoa and in our survey was particularly prevalent in areas that have high year-round rainfall (Western Sumatra and West Papua). The fact that an interaction was observed between spraying against blackpod and duration of the dry season observed in 2014/15 may imply that where farmers sprayed against blackpod, there was higher background levels of Phytophthora fungi and so under such conditions there may have been a positive impact of a subsequent dry period in supressing the spread of blackpod. Other factors that have been shown to contribute to better blackpod control include pruning which improves air circulation in the canopy (Daniel et al. 2011; Prawoto, 2015). An impact of pruning on yield was observed in the 2014/15 model (although not for the subsequent two years); yields were highest when pruning was classified as "moderate" and lowest when "excessive". Pruning practices were highly variable between farms 
and it would thus appear that there is a need for greater training on pruning in some districts. In addition to aiding disease control, when conducted in a systematic manner, pruning facilities more even light capture by the canopy.

A negative association between the amount of weed cover and yields was detected in the 2015/16. The results illustrate of importance of weeding. Weed species can compete with the cocoa for resources (e.g. water and nutrients) but also act as host for insect pests. The negative association between spraying against Helopeltis observed in the model for 2014/15 would appear to be counter intuitive. A possible explanation is that the farms on which greater use of spraying took place are those in which the level of Helopeltis were higher. Thus, the negative association may reflect a higher background level of Helopeltis rather than necessarily a negative impact of spraying.

When it came to environmental influences on yield, an impact of rainfall was seen in 2014/15 and 2015/16. In both years distinct dry periods were observed in many provinces. No association with rainfall was detected in 2016/17 (a La Niña year) when rainfall totals were generally higher and lengths of dry periods were shorter. Thus, it would appear that rainfall was less limiting to yield on many farms for 2016/17.

The analyses of the farms studied here did not show any obvious association between farm-to-farm variation in yields and planting materials, categorised as clonal or seed derived, for the first two years of observation. In the 2016/17 season, whilst not being evident in the multiple regression analysis, a trend of higher yields from clonal trees was observed. Previous studies under uniform conditions have shown the high yield potential of particular clones cultivated in Indonesia (McMahon et al. 2015). It may be that the full yield potential of clonal materials were not expressed on some of the farms studied due to factors such as farm age, soil characteristics etc. There are other advantages of growing clonal cocoa including greater ease of management and harvesting from the more compact trees. Furthermore, side grafting clonal material onto established trees can be a relatively rapid means of rehabilitation of a farm that has matured beyond its productivity peak. A consideration of the contribution of specific clones or hybrids cultivated was beyond the confines of the current study; not all farmers had records of which cultivars they cultivated and so it was not possible to assess this accurately by means of interview. Clearly, the genetics of the crop has the potential to influence farm-to-farm yield variability and have may have accounted for some of the unexplained yield variation. Quantification of the contribution of genetics to on-farm yield variability is more easily quantified through participatory farmer trials, where the same set of clones are grown in multiple locations.

To conclude, this study has demonstrated a very large degree of farm-to-farm variation in yields on Indonesian smallholder cocoa farms. Since at least a part of this yield variability can be associated with specific agricultural practices, there is great potential for yield improvement through optimised farming husbandry.

\section{Acknowledgements}

The author gratefully acknowledge Mondelez International for funding this work.

\section{References}

Belsky J.M. and Siebert S.F. (2003). Cultivating cacao: Implications of sun-grown cacao on local food security and environmental sustainability. Agriculture and Human Values 20, 277-285. 

functional bird diversity in Indonesian cacao agroforestry. Biological Conservation 142, 1032-1041.

Daniel R., Konam J.K., Saul-Maora J.Y., Kamuso A., Namaliu Y., Vano J.T., Wanani R., N’nelau P., Palimrungi R. and Guest, D.I. (2011). Knowledge through participation: the triumphs and challenges of transferring Integrated Pest and Disease Management (IPDM) technology to cocoa farmers in Papua New Guinea. Food Security 3, 65-79. Genetic diversity and parentage in farmer selections of cacao from Southern Sulawesi, Indonesia revealed by microsatellite markers. Breeding Science 65, 438-446.

Draper N.R. and Smith H. (1998). Applied Regression Analysis, $3^{\text {rd }}$ Edition. USA: John Wiley and Sons Ltd.

ICCO (2019). Production of cocoa beans. www.icco.org. Accessed $1^{\text {st }}$ September 2019.

Juhrbandt J., Duwe T., Barkmann J., Gerold G. and Marggraf R. (2010). Structure and management of cocoa agroforestry systems in Central Sulawesi across an intensification gradient. In Tscharntke T., Leuschner C., Veldkamp E., Faust H., Guhardja E. and Bidi A. (eds), Tropical Rainforests and Agroforests under Global Change. Ecological and Socio-economic Valuations. Berlin, Heidelberg, Germany: Springer-Verlag, pp. 115-140.

McMahon P., Bin Purung H., Lambert S., Mulia S., Nurlaila, Susilo A.W., Sulistyowati E., Sukamto S., Israel M., Saftar A., Amir A., Purwantara A., Iswanto A., Guest D. and Keane P. (2015). Testing local selections in three provinces in Sulawesi: (i) Productivity and resistance to cocoa pod borer and Phytophthora pod rot (black pod). Crop Protection 70, 28-39.

McMahon P. and Purwantara A. (2016). Vascular streak dieback (Ceratobasidium theobromae): History and biology. In Bailey B.A. and Meinhardt L.W. (eds), Cacao Diseases: A History of Old Enemies and New Encounters. Switzerland: Springer International Publishing, pp. 307-336. Tjitrosemito S. and Schwendenmann L. (2010). Response of cocoa trees (Theobroma cacao) to a 13month desiccation period in Sulawesi, Indonesia. Agroforestry Systems 79, 171-187.

Mulia S., McMahon P.J., Purwantaeas A., Bin Purung H., Djufry F., Lambert S., Keane P.J. and Guest, D.I. (2019). Effect of organic and inorganic amendments on productivity of cocoa on marginal soil in Sulawesi, Indonesia. Experimental Agriculture 55, 1-20.

Nichols, R. (1964). Studies of fruit development of cacao (Theobroma cacao) in relation to cherelle wilt. I. Development of the pericarp. Annals of Botany 28, 619-635.

Panlibuton H. and Meyer M. (2004). Value chain assessment: Indonesia cocoa. Accelerated Enterprise and ACDI/VOCA for USAID, Washington, DC.

Prawoto A.A. (2015). Improving cocoa yield and suppress pod rot disease through thinning and pruning modifications.
Indonesia, 280-287. Cocoa Supply. Cambridge, UK: Woodhead Publishing Limited. pp. 339-376. 
Ruf F. and Yoddang J. 2001. Cocoa farmers from boom to bust. In Gerard F. and Ruf F. (eds), Agriculture in Crisis: People, Commodities and Natural Resources in Indonesia, 1996-2000. Richmond, UK: Curzon Press. pp. 97-156.

Snoeck D., Koko L., Joffre J., Bastide P. and Jagoret P. (2016). Cacao and nutrition. In Lichtfouse E. (ed), Sustainable Agriculture Reviews. New York: Springer. pp. 155-202.

Sefriadi H., Villano R., Fleming E. and Patrick I. (2013). Production constraints and their causes in the cacao industry in West Sumatra: from the farmers' perspective. International Journal of Agricultural Management 3, 30-42.

Syamsinar R.M., Rukmana D., Nursini and Amal. (2014). Reinvestment acceptance behaviour of cocoa farming (case study of cacao farmer in Luwu Regency). International Journal of Scientific and Technology Research 3, 339-343.

Walkley A. and Black I.A. (1934). An examination of the Degtajareff method for soil organic matter determination and a proposed modification of the chromic acid titration. Soil Science 37, 29-38.

Witjaksono J. and Asmin. (2016). Cocoa Farming System in Indonesia and its sustainability under climate change. Agriculture, Forestry and Fisheries 5, 170-180.

\section{Table legends}

Table 1. Average daily temperature and total annual rainfall across districts in eight different provinces in Indonesia between 2014 and 2016. Figures in brackets are number of consecutive dry months (rainfall total below $20 \mathrm{~mm}$ ) followed by total number of dry months. Temperature data are from on-farm Tinytag datalogger and rainfall data were provided by the Indonesian Meteorological, Climatological, and Geophysical Agency.

Table 2. Parameters initially incorporated into the multiple regression model.

Table 3. Shade trees recorded on across 120 farms in Indonesia

Table 4. Variation in soil nutrient concentrations and $\mathrm{pH}$ across cocoa farms in Indonesia. Each value represents from 15 farms (standard error in brackets)

Table 5. Fitted multiple regression using pod yield data for the seasons 2014/15, 2015/16 and 2016/17. "PS"= pruning score; "BP" = blackpod

Table 6. Districts in which positive associations between rainfall and seasonal yield variation were observed. Relationship are between yields at time " $\mathrm{T}$ " and average daily rainfall during defined preceding months. *Indicates one outlier removed.

\section{Figure legends}

Figure 1. Distribution of yields across farms in Indonesia between those classified as "Highly managed", "Moderately managed" and "Little managed". Values are means over three years (2013/2015, 2015/2016 and 2016/2017). 
490 Figure 2. Variation in yield over three years expressed as pods per tree across eight provinces in 491 Indonesia between May 2014 and June 2017. Values represent means from 15 farms (+/- standard 492 errors).

493 Figure 3. Variation in physical characteristics of cocoa farms surveyed across eight provinces in 494 Indonesia. A. Farm size, B. Tree density, C. Farm age 
Table 1. Average daily temperature and total annual rainfall across districts in eight different provinces in Indonesia between 2014 and 2016. Figures in brackets are number of consecutive dry months (rainfall total below $20 \mathrm{~mm}$ ) followed by total number of dry months. Temperature data are

\begin{tabular}{|l|l|l|l|l|l|l|l|}
\hline Province & District & \multicolumn{5}{|l|}{ Temperature $\left(^{\circ} \mathrm{C}\right)$} & \multicolumn{2}{l|}{ Rainfall (mm) } \\
\cline { 2 - 8 } & & $\mathbf{2 0 1 4}$ & $\mathbf{2 0 1 5}$ & $\mathbf{2 0 1 6}$ & $\mathbf{2 0 1 4}$ & $\mathbf{2 0 1 5}$ & $\mathbf{2 0 1 6}$ \\
\hline W Sumatra & Pariaman & 26.6 & 25.8 & 25.4 & $4855(0,0)$ & $5380(0,0)$ & $5132(0,0)$ \\
& & & & & & & \\
\hline & W Pasaman & 25.1 & 25.3 & 24.9 & $3981(0,0)$ & $4784(0,0)$ & $5092(0,0)$ \\
\hline & Pasaman & 27.6 & 26.3 & 25.9 & $4392(0,0)$ & $4769(0,0)$ & $3825(0,0)$ \\
\hline Lampung & E Lampung & 27.4 & 27.9 & 27.8 & $\#$ & $2052(1,2)$ & $2028(0,0)$ \\
\hline & Pesawaran & 25.7 & 25.0 & 24.8 & $2215(1,1)$ & $1867(3,3)$ & $2378(0,0)$ \\
\hline & Pringsewu & 27.2 & 27.2 & 26.6 & $1960(1,1)$ & $2151(2,4)$ & $2709(0,0)$ \\
\hline East Java & Pacitan & 24.4 & 25.6 & 24.9 & $2542(3,3)$ & $1964(5,5)$ & $3287(0,0)$ \\
\hline & Blitar & 27.5 & 24.8 & 27.1 & $1375(6,6)$ & $1728(6,6)$ & $2316(1,1)$ \\
\hline & Madiun & 25.1 & 27.7 & 24.3 & $1298(3,3)$ & $1748(5,4)$ & $\#$ \\
\hline $\begin{array}{l}\text { W } \\
\text { Sulawesi }\end{array}$ & Majene & 27.6 & 28.1 & 27.7 & $2404(1,1)$ & $2165(3,3)$ & $2484(0,0)$ \\
\hline & Mamuju & 27.6 & 29.3 & 30.2 & $2723(0,0)$ & $2500(0,0)$ & $3392(0,0)$ \\
\hline & $\begin{array}{l}\text { Polewali } \\
\text { Mandar }\end{array}$ & 27.6 & 27.9 & 27.2 & $1378(1,1)$ & $1458(3,3)$ & $1858(0,0)$ \\
\hline C Sulawesi & Parigi & 27.6 & 27.4 & 27.5 & $1673(0,0)$ & $1664(0,0)$ & $1703(0,0)$ \\
& Moutong & & & & & & \\
\hline & Donggala & 27.3 & 28.3 & 27.2 & $1141(1,3)$ & $855(3,4)$ & $4122(0,0)$ \\
\hline & Sigi & 25.3 & 26.3 & 25.2 & $2930(0,0)$ & $2455(1,1)$ & $1936(1,1)$ \\
\hline S Sulawesi & Pinrang & 28.6 & 29.6 & 28.5 & $1615(3,3)$ & $1774(4,4)$ & $1483(0,0)$ \\
\hline & Luwu & 28.6 & 29.0 & 28.2 & $2110(2,2)$ & $1794(4,4)$ & $2308(0,0)$ \\
\hline & Soppeng & 27.0 & 28.1 & 27.7 & $1790(0,0)$ & $1243(4,4)$ & $2017(0,0)$ \\
\hline $\begin{array}{l}\text { SE } \\
\text { Sulawesi }\end{array}$ & Kolaka & 26.1 & 27.1 & 27.1 & $2038(1,1)$ & $1836(4,4)$ & $2706(0,0)$ \\
\hline & Kolaka Utara & 27.5 & 27.5 & 27.1 & $\#$ & $\#$ & $\#$ \\
\hline & Konawe & 26.6 & 28.3 & 27.2 & $2059(2,2)$ & $1343(4,4)$ & $1473(1,2)$ \\
\hline W Papua & Manokwari & 28.9 & $*$ & 27.4 & $1999(0,0)$ & $*$ & $3068(0,0)$ \\
\hline & $\begin{array}{l}\text { South } \\
\text { Manokwari }\end{array}$ & 29.0 & $*$ & 28.0 & $2197(0,0)$ & $*$ & $\#$ \\
\hline & & & & & & \\
\hline
\end{tabular}


507 Table 2: Parameters initially incorporated into the multiple regression model.

\begin{tabular}{|c|c|c|c|}
\hline Parameter & Units & Data Type & Transformation \\
\hline Tree density & Trees per hectare & Variable & Ln-transformed \\
\hline Cocoa light interception & $\%$ & Variable & None \\
\hline Planting material & "Seed", "Clone" or "Mixed" & Factor & - \\
\hline Farm Age & Years & Variable & None \\
\hline Fertiliser addition & "Yes" or "No" & Factor & - \\
\hline Pruning score & $\begin{array}{l}\text { "Little", "Moderate", "Optimum", } \\
\text { "Excessive"** }\end{array}$ & Factor & - \\
\hline Weed cover & $\%$ & Variable & Ln-transformed \\
\hline Spray against blackpod & "Yes" or "No" & Factor & - \\
\hline Spray against cocoa pod borer & "Yes" or "No" & Factor & - \\
\hline Spray against Helopeltis & "Yes" or "No" & Factor & - \\
\hline Presence of shade & "Yes" or "No" & Factor & - \\
\hline Temperature & ${ }^{\circ} \mathrm{C}$ & Variable & None \\
\hline Relative humidity & $\%$ & Variable & None \\
\hline Carbon & $(\%)$ & Variable & Ln-transformed \\
\hline Nitrogen & $(\%)$ & Variable & Ln-transformed \\
\hline Phosphorus & $\mathrm{mg} \mathrm{kg}^{-1}$ & Variable & Ln-transformed \\
\hline Potassium & ${ }_{c} \mathrm{~mol}_{\mathrm{c}} \mathrm{kg}^{-1}$ & Variable & Ln-transformed \\
\hline $\mathrm{pH}$ & $\mathrm{pH}$ scale & Variable & Ln-transformed \\
\hline Total rainfall & $\mathrm{mm}$ & Variable & Ln-transformed \\
\hline $\begin{array}{l}\text { Number consecutive dry } \\
\text { months }^{\#}\end{array}$ & Months & Variable & - \\
\hline $\begin{array}{l}\text { Number non-consecutive dry } \\
\text { months }{ }^{\#}\end{array}$ & Months & Variable & - \\
\hline
\end{tabular}

*Here the modal score across the treks was used

509 "One of these three measures was used in consecutive model fittings 
514 Table 3. Shade trees recorded on across 120 farms in Indonesia

\begin{tabular}{|c|c|c|}
\hline Shade tree grown & $\begin{array}{l}\text { Percentage of } \\
\text { farmers }\end{array}$ & Potential use of shade tree \\
\hline Coconut (Cocos nucifera) & 42.5 & Edible nut \\
\hline Gliricidia sepium & 33.4 & None \\
\hline Banana (Musa paradisiaca) & 16.7 & Edible fruit \\
\hline Durian, King of fruit (Durio zibethinus) & 6.7 & Edible fruit \\
\hline NO SHADE & 5.0 & - \\
\hline Petai (Parkia speciosa) & 4.1 & Edible bean \\
\hline Clove (Eugenia aromatica) & 3.3 & Edible fruit \\
\hline Leucena sp. & 2.5 & Edible fruits, livestock fodder \\
\hline Lansium tree (Lansium domesticum) & 2.5 & Edible fruit \\
\hline Teak (Tectona grandis) & 1.7 & Timber \\
\hline Rambutan (Nephelium lappaceum) & 1.7 & Edible fruit \\
\hline Mango (Mangifera indica) & 1.7 & Edible fruit \\
\hline Albizzia (Paraserianthes falcataria) & 1.6 & Timber/ cattle fodder \\
\hline Sesbania (Sesbania grandiflora) & 0.8 & Edible flowers, medicinal uses \\
\hline Rubber (Hevea brasiliensis) & 0.8 & Rubber tapping \\
\hline Nutmeg (Miristica fragrans) & 0.8 & Edible fruit/ seeds \\
\hline Mindi (Melia azedarach) & 0.8 & Timber \\
\hline Jengkol (Pithecellobium lobatum) & 0.8 & Edible seeds \\
\hline Jack Fruit (Artocarpus heterophyllus) & 0.8 & Edible fruit \\
\hline Globular fruit (Arenga pinnata) & 0.8 & Edible fruit \\
\hline Dadap (Erythrina variegata) & 0.8 & Cattle fodder \\
\hline Cananga tree (Cananga odorata) & 0.8 & Medicinal \\
\hline Balsa (Ochroma pyramidale) & 0.8 & Timber \\
\hline Bayur (Pterospermum javanicum) & 0.8 & Timber \\
\hline Avocado (Persea americana) & 0.8 & Edible fruit \\
\hline Chewing nut (Areca catechu) & 0.8 & Edible nut \\
\hline
\end{tabular}

515 
Table 4. Variation in soil nutrient concentrations and $\mathrm{pH}$ across cocoa farms in Indonesia. Each value represents from 15 farms (standard error in brackets)

\begin{tabular}{|c|c|c|c|c|c|c|}
\hline & C (\%) & $\mathbf{N}(\%)$ & $P\left(\mathrm{mg} \mathrm{kg}^{-1}\right)$ & $\mathrm{K}\left(\mathrm{cmol}_{\mathrm{c}} \mathrm{kg}^{-1}\right)$ & $\mathrm{Mg}\left({ }_{\mathrm{cmol}} \mathrm{kg}^{-1}\right)$ & $\mathrm{pH}$ \\
\hline W Sumatra & $5.56(0.81)$ & $0.56(0.08)$ & $56.1(18.1)$ & $0.60(0.07)$ & $1.81(0.33)$ & $4.79(0.09)$ \\
\hline Lampung & $1.77(0.81)$ & $0.20(0.02)$ & $51.6(18.1)$ & $0.57(0.05)$ & $2.30(0.19)$ & $5.35(0.07)$ \\
\hline East Java & $0.99(0.09)$ & $0.10(0.01)$ & 74.8 (18.6) & $0.70(0.07)$ & $2.42(0.49)$ & $5.34(0.16)$ \\
\hline W Sulawesi & $1.55(0.22)$ & $0.18(0.02)$ & $77.2(9.0)$ & $0.78(0.07)$ & $4.52(0.45)$ & $5.01(0.21)$ \\
\hline C Sulawesi & $1.60(0.16)$ & $0.17(0.02)$ & $70.7(8.4)$ & $0.69(0.04)$ & $2.44(0.31)$ & $5.24(0.15)$ \\
\hline S Sulawesi & $1.54(0.19)$ & $0.15(0.01)$ & 76.5 (18.5) & $0.82(0.01)$ & $4.67(0.37)$ & $5.43(0.21)$ \\
\hline SE Sulawesi & $1.25(0.13)$ & $0.14(0.01)$ & $75.0(9.5)$ & $0.37(0.05)$ & $1.36(0.19)$ & $5.08(0.17)$ \\
\hline W Papua & $3.49(0.61)$ & $0.38(0.08)$ & $23.5(4.0)$ & $0.53(0.06)$ & $2.97(0.56)$ & $5.54(0.17)$ \\
\hline ANOVA & $P<0.001$ & $P<0.001$ & $P=0.056$ & $P<0.001$ & $P<0.001$ & $P<0.001$ \\
\hline
\end{tabular}

Table 5. Fitted multiple regression using pod yield data for the seasons 2014/15, 2015/16 and

\begin{tabular}{|c|c|c|c|c|c|}
\hline \multicolumn{2}{|l|}{2014} & \multicolumn{2}{|l|}{2015} & \multicolumn{2}{|l|}{2016} \\
\hline Parameter & Estimate & Parameter & Estimate & Parameter & Estimate \\
\hline Constant & 121.5 & Constant & 13.7 & Constant & -177.2 \\
\hline Cumulative dry months & -0.31 & Ln Rainfall (mm) & 10.56 & Cocoa LI (\%) & 0.491 \\
\hline Fertiliser= yes & 11.4 & $\operatorname{Ln} C(\%)$ & -10.21 & $\operatorname{Ln~K}\left({ }_{c} \mathrm{~mol}_{\mathrm{c}} \mathrm{kg}^{-1}\right)$ & -15.64 \\
\hline Humidity (\%) & -1.308 & $\operatorname{Ln~K}\left({ }_{c} \mathrm{~mol}_{\mathrm{c}} \mathrm{kg}^{-1}\right)$ & -8.53 & $\operatorname{Ln} \mathrm{P}\left(\mathrm{mg} \mathrm{kg}^{-1}\right)$ & 5.97 \\
\hline $\operatorname{Ln~K}\left({ }_{c} \mathrm{~mol}_{\mathrm{c}} \mathrm{kg}^{-1}\right)$ & -7.1 & $\operatorname{Ln} P\left(\mathrm{mg} \mathrm{kg}^{-1}\right)$ & 4.28 & Temperature $\left({ }^{\circ} \mathrm{C}\right)$ & 5.55 \\
\hline$P S=$ LesS & 2.8 & $\begin{array}{l}\text { Ln Density (trees } \\
\mathrm{ha}^{-1} \text { ) }\end{array}$ & -9.27 & & \\
\hline PS $=$ Moderate & 24.5 & Ln Weed cover (\%) & -5.60 & & \\
\hline PS = Optimum & 6.3 & Spray for $\mathrm{BP}=\mathrm{Yes}$ & 8.63 & & \\
\hline $\mathrm{PS}=$ Variable & 4 & & & & \\
\hline Spray for BP $=$ Yes & 2.31 & & & & \\
\hline Spray for Helopeltis $=$ Yes & -8.38 & & & & \\
\hline $\begin{array}{l}\text { Cumulative dry months } \\
{ }^{*} \text { Spray for } \mathrm{BP}=\mathrm{Yes}\end{array}$ & 8.92 & & & & \\
\hline Reference factors & & Reference factors & & & \\
\hline PS $=$ Excessive & & & & & \\
\hline Spray for BP $=$ No & & Spray for $\mathrm{BP}=$ No & & & \\
\hline Spray for Helopeltis $=$ No & & & & & \\
\hline
\end{tabular}


Table 6. Districts in which positive associations between rainfall and seasonal yield variation were observed. Relationship are between yields at time " $T$ " and average daily rainfall during defined preceding months. *Indicates one outlier removed.

\begin{tabular}{|l|l|l|l|}
\hline District (Province) & Rainfall months & Relationship & $\mathbf{r}^{\mathbf{2}}$ \\
\hline Pringsewu & $\begin{array}{l}\text { Average of T-4, T-5 and T- } \\
6\end{array}$ & Positive linear & $0.45^{*}$ \\
\hline Pesawaran & $\begin{array}{l}\text { Average of T-4, T-5 and T- } \\
6\end{array}$ & Rectangular hyperbola & 0.78 \\
\hline Soppeng & T-6 & Positive linear & 0.37 \\
\hline Konawe & Average of T-4 and T-5 & Positive linear & $0.43^{*}$ \\
\hline
\end{tabular}

535

536

537 
538 FIGURE 1

539

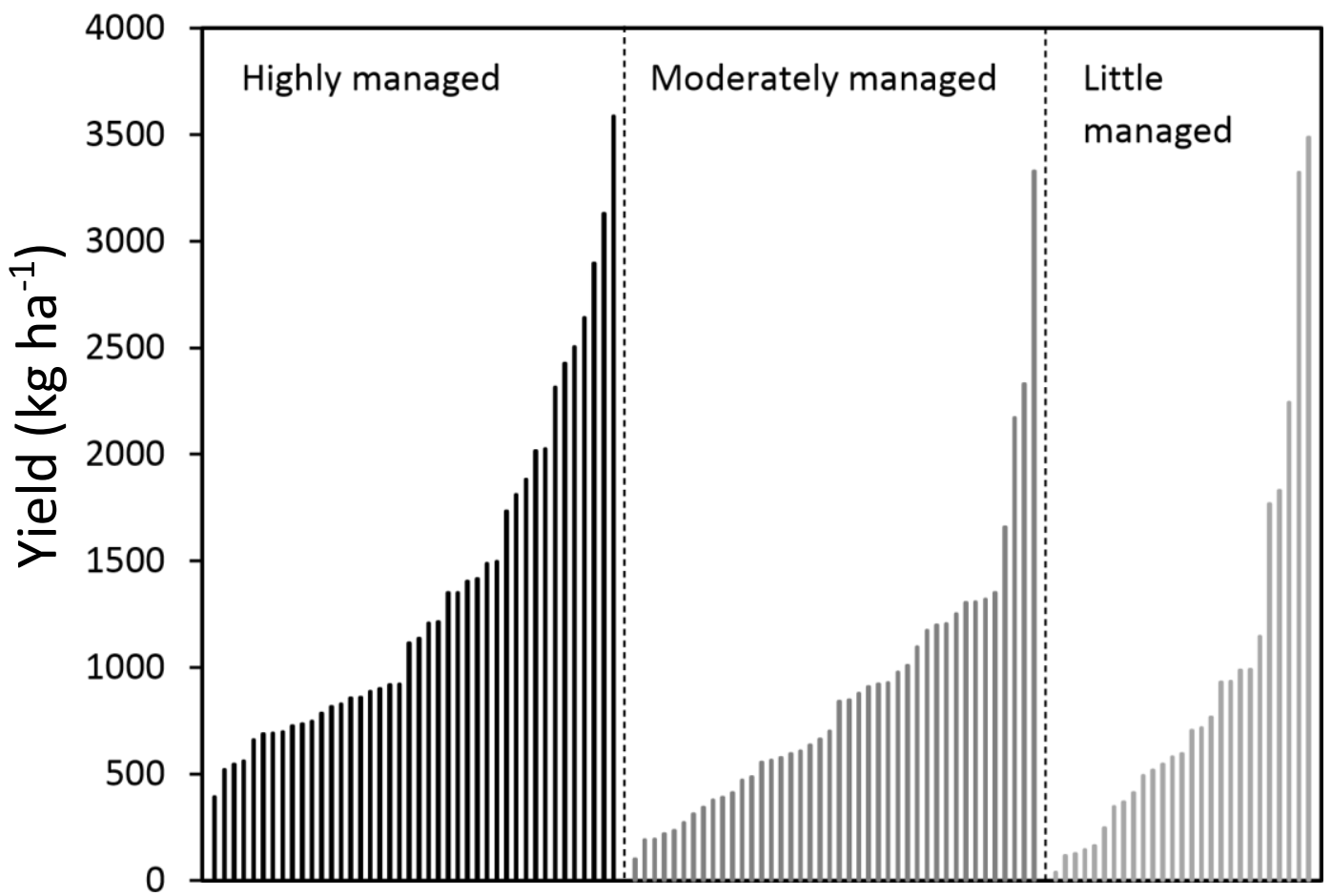

541

Individual farms

542

543

544 


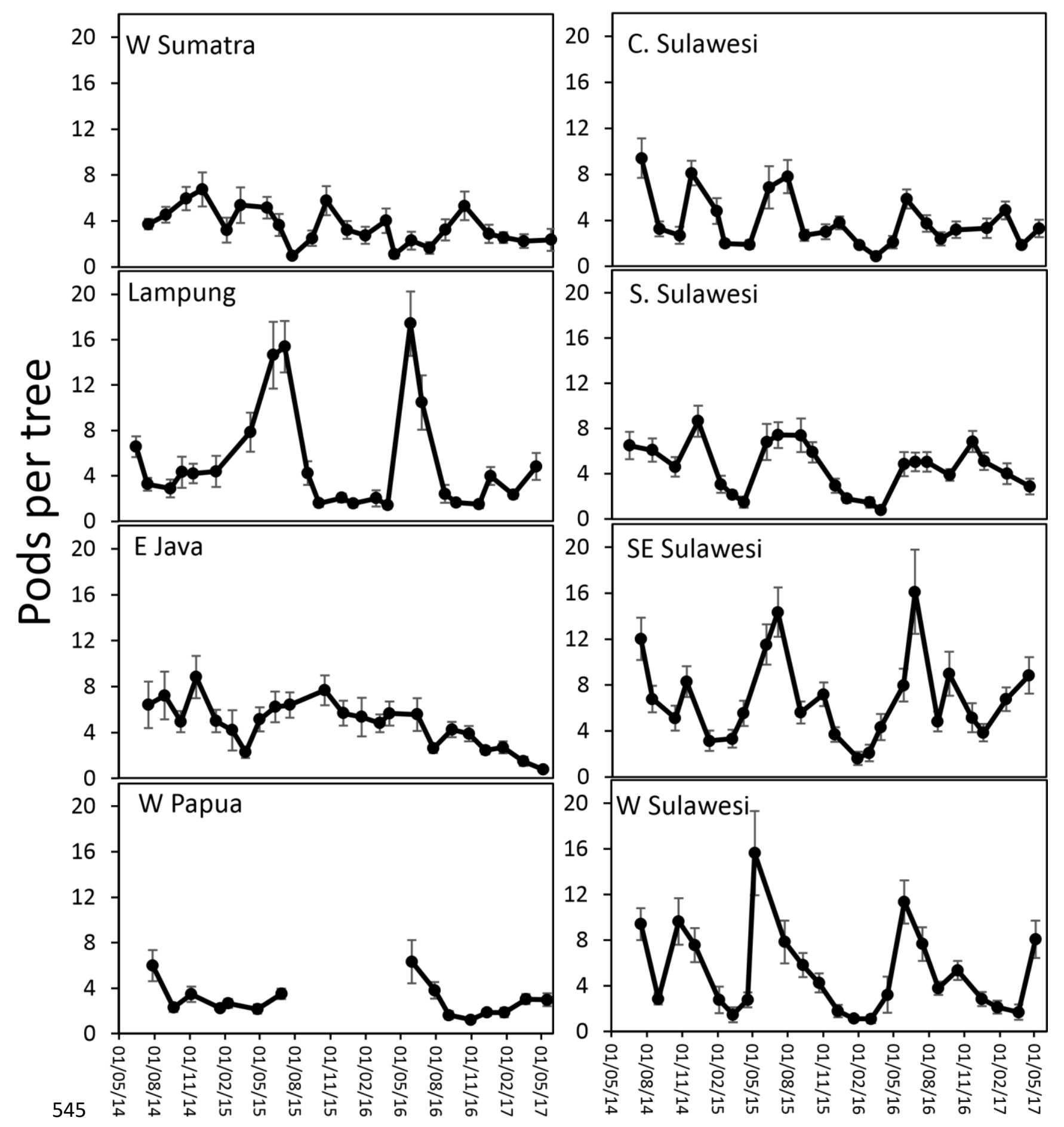

546 FIGURE 2

547 


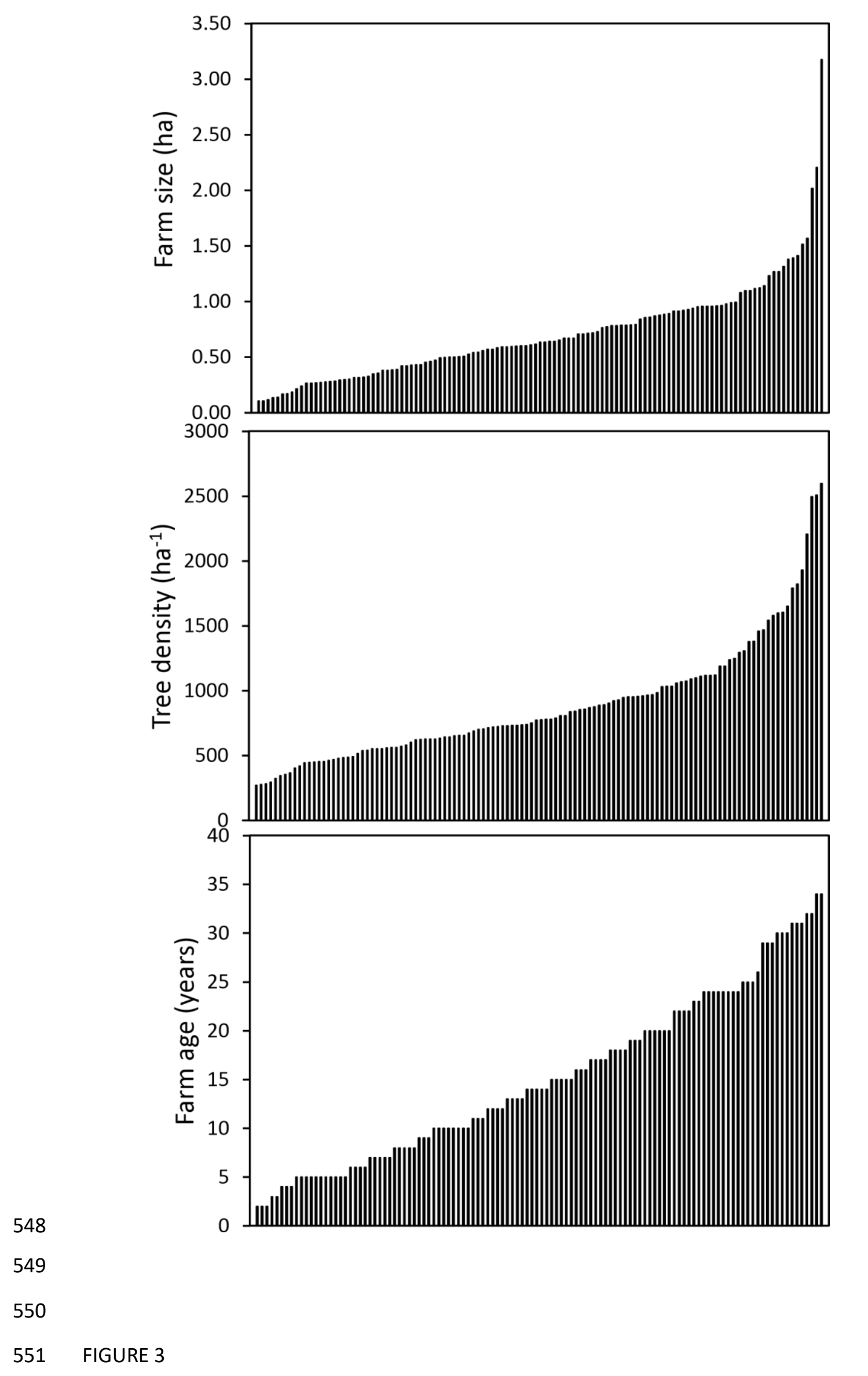

